J. Bangladesh Acad. Sci., Vol. 42, No. 2, 111-120, 2018

DOI: https://doi.org/10.3329/jbas.v42i2.40038

\title{
EXPLORATION OF ANTI-DIABETIC, ANTI-DIARRHEAL, GASTROINTESTINAL MOTILITY AND ACUTE TOXICITY OF DIFFERENT EXTRACTS OF CITRUS ASSAMENSIS LEAF
}

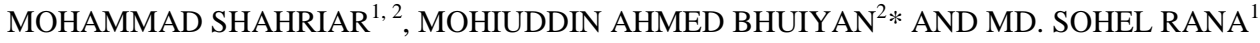 \\ Phytochemistry Research Laboratory, Department of Pharmacy, University of Asia Pacific, Dhaka, Bangladesh
}

\begin{abstract}
Citrus assamensis (Family: Rutaceae), commonly known as Satkara, is a pharmacologically diverse medicinal plant. In the present study, the leaf extracts of $C$. assamensis were subjected to evaluate in vitro anti-diabetic as well as in vivo anti-diarrheal, gastrointestinal motility and acute toxicity activity on Swiss albino mice by using standard protocol. Ethanol and chloroform extracts showed significant inhibitory potentials $(* * \mathrm{p}<0.01)$ against in vitro $\alpha$-amylase enzyme at the concentration of $80 \mu \mathrm{g} / \mathrm{mL}$. Significant $(* \mathrm{p}<0.05, * * \mathrm{p}<0.01, * * * \mathrm{p}<0.001)$ reduction in the number of wet feces and percentage inhibition of diarrheal activity over three hours was observed with all the test doses of the extract compared with the vehicle treated group. Both doses of methanol and ethanol extracts $(* \mathrm{p}<0.05)$ and chloroform extract at doses of $100 \mathrm{mg} / \mathrm{kg}$ significantly reduced the number of wet feces compared to the control. None of the extracts showed any significant in vivo acute toxicity effect on mice.
\end{abstract}

Key words: Citrus assamensis, anti-diabetic, anti-diarrheal, gastrointestinal motility, acute toxicity

\section{INTRODUCTION}

Diabetes mellitus is the world's largest endocrine disease of multiple etiologies involving metabolic disorders of carbohydrate, fat and protein. It is estimated that the global prevalence of diabetes is increasing each year causing a major burden to the health sector, especially in the developing countries (Wickramaratne et al. 2016) where $90 \%$ is accounted to be type II diabetic (ADA, 2012). Patients with type II diabetes can be easily treated with dietary changes, exercise, and medication. The complications arising with diabetes are closely related to the production of free radicals enhancing the oxidative stress ( $\mathrm{Ab}$ Hamid et al. 2010). Hence the use of antioxidants has been effective in reducing the severity of diabetic complications (Roberts et al. 2007). At present the treatment of diabetes

mainly involves a sustained reduction in hyperglycemia by the use of biguanides, thiazolidinediones, sulfonylureas, d-phenylalanine and glycosidase inhibitors in addition to insulin. However, due to unwanted side effects the efficacies of these compounds are debatable and there is a demand for new compounds for the treatment of diabetes (Naim et al. 2012). The anti-diabetic agents from Citrus plants are very promising and traditionally acclaimed medicinal plants are being investigated for their antidiabetic potential (Kabra et al. 2012; Peng et al. 2009; Jung et al. 2006; Gyo-Nam et al. 2009; Ernawita et al. 2016; Kundu Sen et al. 2011; Wadkar et al. 2008; Oyedepot and Babarinde, 2012; Laboni et al. 2017).

Globally there are a number of epidemiological

\footnotetext{
* Corresponding author: <mohiuddin@uap-bd.edu>.

${ }^{1}$ Department of Pharmacy, Jahangirnagar University, Savar, Dhaka, Bangladesh.

${ }^{2}$ Phytochemistry Research Laboratory, Department of Pharmacy, University of Asia Pacific, Dhaka, Bangladesh.
} 
and experimental evidences worldwide related to acute diarrheal disease as it is the second leading cause of death in children under five, and responsible for the deaths of about 760,000 children every year (WHO, 2013). As an intervention of diarrhea, many antidiarrheal agents elicit effects by reducing the gastrointestinal motility and/or the secretions (Gutiérrez et al. 2013). Although currently used drugs are important in the management of diarrhea, they still are linked with adverse effects and contraindications. Understanding the disease risk and identifying determinants of seeking care from a professional healthcare provider may provide a basis upon which governments can estimate the burden of the disease and detect barriers to seeking appropriate healthcare. This is particularly important in countries like Bangladesh, where a large proportion of the population is below the poverty line (Chowdhury et al. 2015). Despite immense technological advancement in modern medicine, many people in the developing countries still rely on healing practices and medicinal plants (Tadesse et al. 2014) as a remedy against diarrhea. Therefore, identification of new source of anti-diarrheal drugs becomes one of the most prominent focuses in modern research.

Laxatives are drugs which promote defecation which can also be managed by increased dietary intake of fibers, regular exercise, adequate water intake and bowel training with reassurance. In some cases where constipation is a manifestation of organic disease or some other systemic ailment, then treatment of the underlying disease should be the primary focus of therapy.

Citrus genus belongs to the large family Rutaceae, containing 130 genera in the seven subfamilies with many important fruit and essential oil producers (Lucker et al. 2002). Citrus assamensis, locally known as Satkora in
Bangladesh, is a small tree, moderately branched and thorny plant of the family Rutaceae, which is used as medicine by local tribes of Assam, India. Preliminary phytochemical investigation of $C$. assamensis leaf extract suggested the presence of alkaloids, tannins, reducing sugars and flavonoids (Mahmood et al. 2013). The leaf extract of $C$. assamensis demonstrated to have thrombolytic activity (Mahmood et al. 2013). Leaves, flowers, and fruits of $C$. assamensis are used for treating dysentery, indigestion, pimples and intestinal worms (Das et al. 2013).

However, so far, there is no report demonstrating the in vitro and in vivo biological activities of $C$. assamensis plant extract, which prompted us to design the present study to evaluate the in vitro anti-diabetic as well as in vivo anti-diarrheal, gastrointestinal motility and acute toxicity activity on Swiss albino mice by using the organic soluble materials of the leaf extracts of $C$. assamensis for the first time.

\section{MATERIALS AND METHODS}

\section{Collection, identification and processing of plant samples}

Leaves of $C$. assamensis were collected from Jayantapur, Sylhet, Bangladesh and the plant was taxonomically identified with the help of the National Herbarium of Bangladesh, Mirpur, Dhaka (DACB; Accession Number- 38759). Leaves were sun dried for seven days. The dried leaves were then ground in coarse powder using high capacity grinding machine (Jaipan Designer Mixer Grinder, India) which was then stored in air-tight container with necessary markings for identification and kept in cool, dark and dry place for investigation.

\section{Extraction procedure}

The powdered plant parts $(30 \mathrm{gm})$ were successively extracted in a soxhlet extractor at 
elevated temperature using $500 \mathrm{~mL}$ of distilled methanol at $(40-60){ }^{\circ} \mathrm{C}$ which was followed by ethanol and chloroform. After extraction all extracts were kept in refrigerator $\left(4^{\circ} \mathrm{C}\right)$ for further investigations with their necessary markings for identification.

\section{Experimental animal}

Swiss albino mice of either sex, 4-5 weeks of age, weighing between 10-24 gm were collected from ICDDR,B, Dhaka. Animals were maintained under standard environmental conditions and free access to feed and water. The animals were acclimatized to laboratory condition for one week prior to experiments. All protocols for animal experiment were approved by the institutional animal ethical committee.

In vitro Anti-diabetic study

For in vitro anti-diabetic study $\alpha$-amylase inhibition assay was performed using the 3,5dinitrosalicylic acid (DNSA) method (Miller 1959). The leaf extract of C. assamensis was dissolved in minimum amount of $10 \%$ DMSO and was further dissolved in buffer $\mathrm{Na}_{2} \mathrm{HPO}_{4} / \mathrm{NaH}_{2} \mathrm{PO}_{4}(0.02 \mathrm{M}), \mathrm{NaCl}(0.006 \mathrm{M})$ at $\mathrm{pH}$ 6.9) to give concentrations ranging from 10 to $1000 \mu \mathrm{g} / \mathrm{mL}$. A volume of $200 \mu \mathrm{L}$ of $\alpha$ amylase solution ( 2 units $/ \mathrm{mL}$ ) was mixed with $200 \mu \mathrm{L}$ of the extract and was incubated for 10 $\min$ at $30^{\circ} \mathrm{C}$. Thereafter $200 \mu \mathrm{L}$ of the starch solution $(1 \%$ in water $(\mathrm{w} / \mathrm{v}))$ was added to each tube and incubated for $3 \mathrm{~min}$. The reaction was terminated by the addition of $200 \mu \mathrm{L}$ DNSA reagent $(12 \mathrm{~g}$ of sodium potassium tartrate tetrahydrate in $8.0 \mathrm{~mL}$ of $2 \mathrm{M} \mathrm{NaOH}$ and $20 \mathrm{~mL}$ of $96 \mathrm{mM}$ of 3,5-dinitrosalicylic acid solution) and was boiled for $10 \mathrm{~min}$ in a water bath at 85 $90^{\circ} \mathrm{C}$. The mixture was cooled to ambient temperature and was diluted with $5 \mathrm{~mL}$ of distilled water, and the absorbance was measured at $540 \mathrm{~nm}$ using a UV-Visible spectrophotometer. The blank with $100 \%$ enzyme activity was prepared by replacing the plant extract with $200 \mu \mathrm{L}$ of buffer. A blank reaction was similarly prepared using the plant extract at each concentration in the absence of the enzyme solution. A positive control sample was prepared using Acarbose $(100 \mu \mathrm{g} / \mathrm{mL}-2$ $\mu \mathrm{g} / \mathrm{mL}$ ) and the reaction was performed similarly to the reaction with plant extract. The $\alpha$-amylase inhibitory activity was expressed as percent inhibition and was calculated using the equation given below:

$\% \alpha$-amylase inhibition $=100 \times$ Abs $100 \%$ control-

$\mathrm{Abs}_{\text {sample }} / \mathrm{Abs}_{100 \%}$ control

In vivo Anti-diarrheal activity

The anti-diarrheal activity was performed by the method developed by Havagiray et al. (2004). Animals were divided into 8 groups of six animals in each group. Group I received $1 \%$ CMC suspension and served as control. Group II received standard drug, (loperamide $2 \mathrm{mg} / \mathrm{kg}$ ) and served as standard (Sunilson et al. 2009). Group III-IV received methanol extract of $C$. assamensis (100 and $200 \mathrm{mg} / \mathrm{kg}$ ). Groups V-VI received ethanol extract of $C$. assamensis (100 and $200 \mathrm{mg} / \mathrm{kg}$ ). Groups VII-VIII received chloroform extract of C. assamensis (100 and $200 \mathrm{mg} / \mathrm{kg}$ ). Diarrhea was induced in all the overnight fasted animals by administering $1 \mathrm{~mL}$ of castor oil orally. The test extracts and the standard drug were administered one hour prior to the treatment of castor oil. Each group received the same treatment under similar conditions and three personnels were engaged for the observations over $4 \mathrm{hrs}$. Thereafter, they were observed for the presence of diarrhea defined as watery (wet), unformed stool. The anti-diarrheal activity was determined in terms of percentage protection or inhibition (Akuodor et al. 2011). 
In vivo Gastrointestinal (GI) motility determination

Forty eight Swiss Albino mice, weighing between (15-30) gm were selected and housed properly for 7 days before performing the experiment. On the test day, the animals were divided into 8 groups of 6 mice each. They were weighed and deprived of food, with free access to water. Three hours after food deprivation, the animals in group 1 received orally by gavages 5 $\mathrm{mL} / \mathrm{kg}$ body weight of $0.9 \% \mathrm{NaCl}$ (normal saline) as control group, while those in group 2 received $5 \mathrm{mg} / \mathrm{kg}$ b.w (body weight) of butapen as standard group. The other six groups received their respective doses as shown in Fig. 4; 100 $\mathrm{mg} / \mathrm{kg}$ body weight and $200 \mathrm{mg} / \mathrm{kg}$ doses of methanol, ethanol and chloroform extracts were used. After $90 \mathrm{~min}, 0.3 \mathrm{~mL}$ of an aqueous suspension of $5 \%$ charcoal in normal saline was administered to each animal orally by gavages (time $90 \mathrm{~min}$ ). Sixty minutes later they had free access to food (time $150 \mathrm{~min}$ ). The animals were observed at $5 \mathrm{~min}$ intervals until feces with charcoal were eliminated (maximum time of observation was $300 \mathrm{~min}$ ). Charcoal was observed on the feces using normal light when it was easily visible, or using a microscope to help the identification of the black spots. The results were based on the time for the charcoal to be eliminated (Marona and Lucchesi, 2004; Khandaker et al. 2016). Percentage inhibition of diarrhea was calculated as follows:

$\%$ inhibition of diarrhea $=$ Mean Number of wet defecation (control - test) / Mean wet defecation of control $\times 100$.

\section{In vivo Acute toxicity test}

The acute oral toxicity studies of extracts were carried out as per the OECD guidelines, draft guidelines 423 adopted on $17^{\text {th }}$ December 2001 received from CPCSEA, Ministry of Social Justice and Empowerment, 2000, Government of India. Mice were kept fasting for 1-2 hours but water was provided and were divided into 6 groups containing 6 mice in each group. All mice were weighed and kept separated using separate cage. The test samples, i.e. methanol, ethanol and chloroform extracts were administered orally at different doses of 500 $\mathrm{mg} / \mathrm{kg}, 1000 \mathrm{mg} / \mathrm{kg}$, and $2000 \mathrm{mg} / \mathrm{kg}$ of body weight of mice. After administration of the extract solutions mortality or sign of any toxicity was observed for four hour and kept under observation for 2 weeks.

\section{Statistical analysis}

Data was expressed as mean \pm SEM (Standard error of mean). The results were analyzed statistically followed by independent sample $t$-test. Results with $\mathrm{p}<0.05, \mathrm{p}<0.01$ and $\mathrm{p}<0.001$ were considered statistically significant.

\section{RESULTS AND DISCUSSION}

\section{In vitro Anti-diabetic study}

In this study, the $\alpha$-amylase inhibitory activity of the leaves of $C$. assamensis was investigated which is presented in Fig. 1. The percentage inhibition of $\alpha$-amylase by the extracts of $C$. assamensis was studied in a concentration range of $10-100 \mu \mathrm{g} / \mathrm{mL}$. Of the three extracts, ethanol and chloroform were comparatively more effective than methanol and standard that showed significant inhibitory potentials $(* * p<0.01)$ against $\alpha$-amylase enzyme at the concentration of $80 \mu \mathrm{g} / \mathrm{mL}$. 


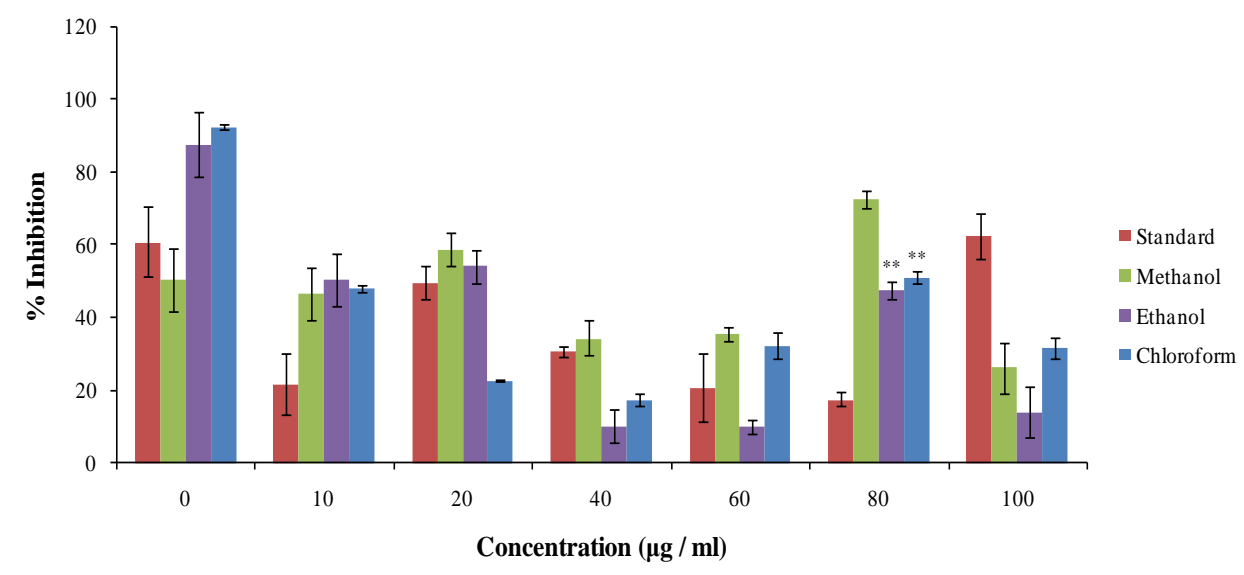

Fig.1. Anti-diabetic activity (\% inhibition) of different extracts of $C$. assamensis leaf

Values are mean $\pm \operatorname{SEM}(n=6), * *(p<0.01)$ significantly different when compared with the corresponding value of control group, done by independent sample t-test

The trend in the screening of medicinal plants for anti-diabetic activity has increased, as it is important to discover novel effective drugs for the disease. The plant-based $\alpha$-amylase inhibitor offers a prospective therapeutic approach for the management of diabetes (McCue et al. 2004). There are many enzymes in the human digestive system that help in the digestion of food. These $\alpha$-amylase inhibitors are also called as starch blockers because they prevent dietary starch from being absorbed by the body and thereby lower postprandial glucose levels. $\alpha$-amylases hydrolyze complex polysaccharides to produce oligosaccharides and disaccharides which are then hydrolyzed by $\alpha$-glycosidase to monosaccharide which are absorbed through the small intestines into the hepatic portal vein and increase postprandial glucose levels (Ranilla et al. 2010; El-Kaissi and Sherbeeni, 2011; Kumar et al. 2010). From the literature review it was observed that the methanol extract of Citrus macroptera had moderate $\alpha$-amylase inhibitory activity $\mathrm{IC}_{50}=3.638 \mathrm{mg} / \mathrm{mL}$ (Uddin et al. 2014) and $\mathrm{IC}_{50}=135.354 \mu \mathrm{g} / \mathrm{mL}$ (Vasu et al. 2017) as compared to acarbose. Abirami et al. (2014) reported that the $\alpha$-glucosidase inhibition activities of $C$. hystrix, $C$. maxima and $C$. maxima were $70.68 \%, 72.83 \%$, and $71.88 \%$, respectively. The $\alpha$-amylase inhibitory studies performed in this study demonstrated that the ethanol and chloroform extract of the plant showed maximum $\alpha$ - amylase inhibitory activity which could be attributed to the presence of polyphenols and flavonoids because polyphenols are not only capable of reducing oxidative stress but also of inhibiting carbohydrate hydrolyzing enzymes because of their ability to bind with proteins (Keerthana et al. 2013). The reaction mechanisms involved in inhibition of alpha amylase enzymes by plant protein inhibitors are not clearly understood. But there are some suggestions that the plant protein might cause conformational changes in its structure. Since $C$. assamensis leaf extracts possesses in vitro $\alpha$ amylase inhibitory activity it could be a good candidate for anti-diabetic evaluations in animal models. 
In vivo Anti-diarrheal activity

In case of castor oil induced diarrheal test, the methanol, ethanol and chloroform extract of $C$. assamensis showed considerable anti-diarrheal effect in mice (Figs. 2 and 3). Both doses of wet feces compared to the control. Diarrhea is usually considered a result of altered motility and fluid accumulation within the intestinal tract. After oral ingestion of castor oil, ricinoleic acid is released by lipases in the intestinal

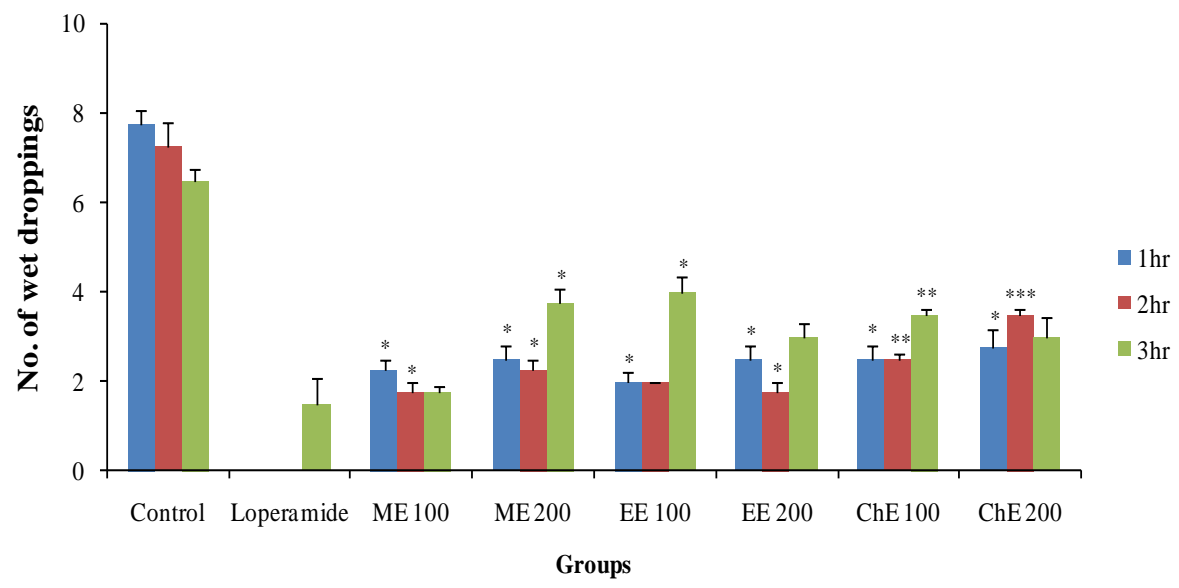

Fig. 2. Anti-diarrheal activity (no. of wet droppings) of different extracts of $C$. assamensis leaf

Values are mean $\pm \operatorname{SEM}(n=6), *(p<0.05), * *(p<0.01), * * *(p<0.001)$ significantly different when compared with the corresponding value of control group, done by independent sample t-test

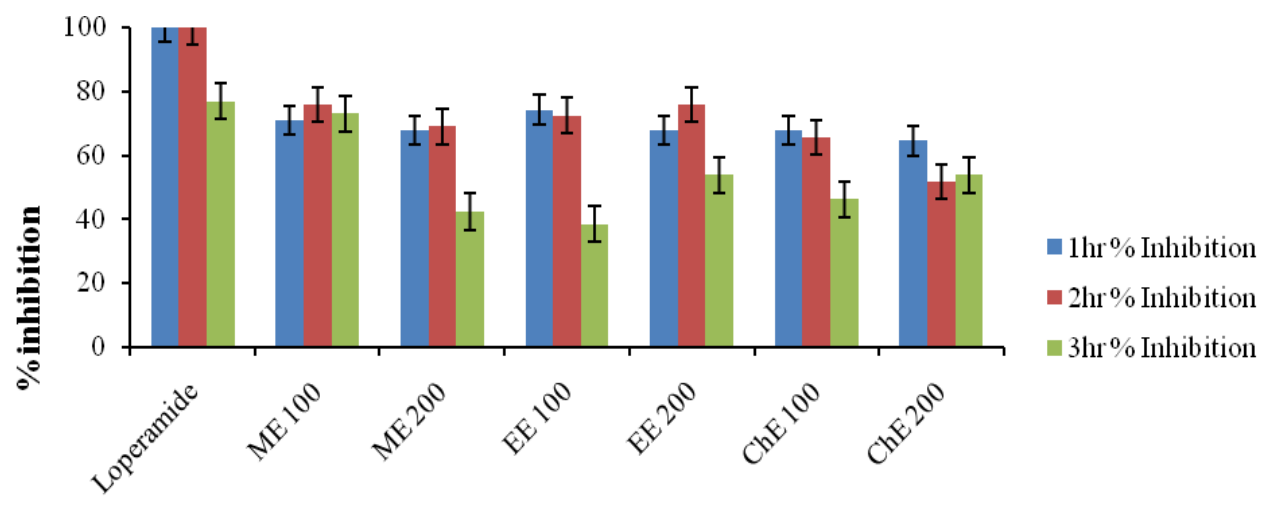

Groups

Fig. 3. Anti-diarrheal activity (\% inhibition) of different extracts of $C$. assamensis leaf

methanol and ethanol extracts $(* \mathrm{p}<0.05)$ and chloroform extract at doses of $100 \mathrm{mg} / \mathrm{kg}$ $(* \mathrm{p}<0.05, * * \mathrm{p}<0.01)$ and $200 \mathrm{mg} / \mathrm{kg} \quad(* \mathrm{p}<0.05$, $* * * \mathrm{p}<0.001)$ significantly reduced the number of lumen, and considerable amounts of ricinoleic acid are absorbed in the intestine (Meyer, 1890; Watson and Gordon, 1962) thereby increases peristaltic activity of small intestine (Palombo, 
2006). Prostaglandins are associated with changes in the bowel that stimulate diarrhea because secretion of endogenous prostaglandin is also stimulated by ricinoleate (Yoshio et al. 1999). Castor oil, which is used as an inducer of diarrhea in this study, is known for its laxative effects because of the active principle, retinoic acid. The active principle of castor oil is known to change the electrolyte permeability of the intestinal membrane and through elevated prostaglandin biosynthesis and release it causes diarrhea similar to pathophysiologic conditions that cause diarrhea (Besra et al. 2002; Brijesh et al. 2009). In the present study, significant reduction in the number of wet feces and percentage inhibition of diarrheal activity over three hours was observed with all the test doses of the extract compared with the control group. The standard drug also showed a marked \% inhibition of diarrheal activity compared to control group, which was by far the highest of all. Plant extracts containing tannin, flavonoids, alkaloids, saponins and steroids have been reported to possess anti-diarrheal activity (Shemsu et al. 2013; Balaji et al. 2012). Presence of alkaloids, tannins, reducing sugars and flavonoids was also observed in $C$. assamensis leaf extract (Mahmood et al. 2013).
From the literature review it was observed that, Citrus limon significantly reduced $(p<0.05)$ the number of wet fecal pellets produced by animals, with $20 \mathrm{mg} / \mathrm{kg}$ hexane extract of Citrus limon peel producing the highest percentage inhibition (Adeniyi et al. 2017). From the results, we found the extracts suppressed the propulsion of charcoal meal by increasing the absorption of water and electrolytes. The remarkable anti-diarrheal effect of $C$. assamensis leaf extracts against castor oil-induced diarrhea model proves its efficacy in an extensive range of diarrheal conditions.

In vivo Gastrointestinal (GI) motility determination

In-vivo gastrointestinal motility test was conducted on methanol, ethanol and chloroform extracts with the doses of $100 \mathrm{mg} / \mathrm{kg}$ and 200 $\mathrm{mg} / \mathrm{kg}$. Gastrointestinal motility describes the contraction of the muscles that mix and propel contents in the gastrointestinal tract. Charcoal meal test in mice is a method used to study the effect of drugs on the motility of intestine. The duration between charcoal administration and charcoal defecation is measured for gastrointestinal motility determination. Fig. 4 shows that the ethanol $200 \mathrm{mg} / \mathrm{kg}$ extract and

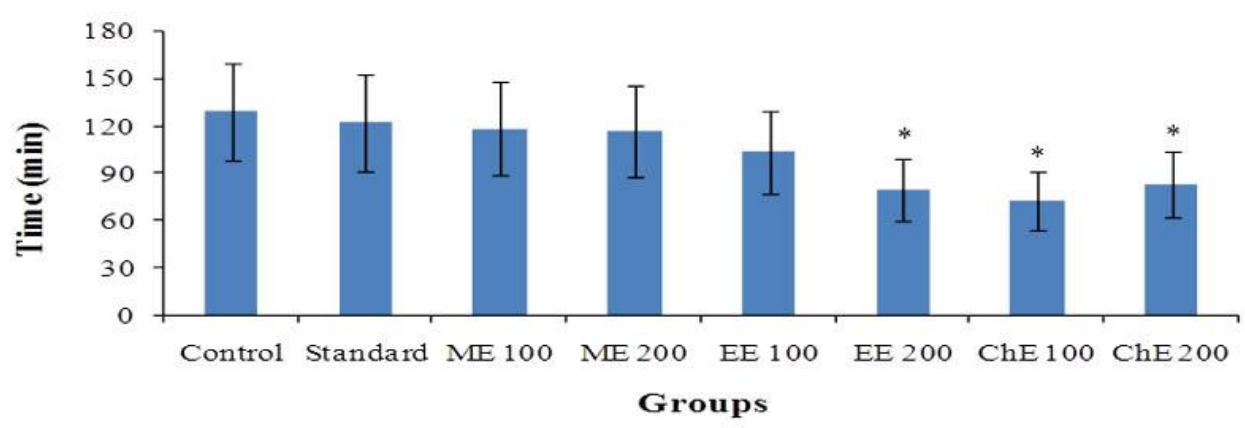

Fig. 4. Time of defecation at gastrointestinal motility activity after administration of doses of control, standard and leaf extracts of $C$. assamensis

Values are mean $\pm \operatorname{SEM}(n=6)$, * $(p<0.05)$ significantly different when compared with the corresponding value of control group, done by independent sample t-test 
both the extracts of chloroform $(100 \mathrm{mg} / \mathrm{kg}, 200$

$\mathrm{mg} / \mathrm{kg}) \quad$ showed significant $\quad(* \mathrm{p}<0.05)$ gastrointestinal motility effect compared to the control.

\section{In vivo Acute toxicity test}

In acute toxicity study, none of the studied extracts of $C$. assamensis leaves showed any significant toxicity sign when observed for the parameters during the first $4 \mathrm{hrs}$, followed by daily observations for 2 weeks and mortality was also not observed; the drug was found to be safe at the tested dose level of $2000 \mathrm{mg} / \mathrm{kg}$.

\section{CONCLUSION}

Some chemical and biological investigations have been carried out on Citrus assamensis plant in this study mainly focusing on the leaf of the plant but those are considered to be preliminary. As a result more research is necessary to reach a concrete conclusion about the finding of the present study. On the basis of above result and available reports, all three leaf extracts of $C$. assamensis has potent in vivo anti-diarrheal and GI motility effects. However, isolating new bioactive compounds and evolution of their extracts mode of action and chronic toxicity profile might be the next steps to be followed to eventually find new lead compounds. The plant can be further screened against various diseases in order to find out its unexplored efficacy and can be a potential source of chemically interesting and biologically important drug candidates.

\section{REFERENCES}

Ab Hamid, M. R., Z. Mustafa, N. R. M. Suradi, F. Idris and M. Abdullah. 2010. Multi-factor of employee values: A confirmatory factor analytics (CFA) validation. Afr. J. Business Management. 5(32): 12632-12640.
Abirami A., G. Nagarani and P. Siddhuraju. 2014. In vitro antioxidant, anti-diabetic, cholinesterase and tyrosinase inhibitory potential of fresh juice from Citrushystrix and C. maxima fruits. Food Sci. Hum. Wellness. 3: 16-25.

Adeniyi, O. S., J. Omale, S. C. Omeje and V. O. Edino. 2017. Antidiarrheal activity of hexane extract of Citrus limon peel in an experimental animal model. J. Integr. Med. 15(2): 158-164.

Akuodor, G. C., I. Muazzam, M. Usman-Idris, U. A. Megwas, J. L. Akpan, K. C. Chilaka, D. O. Okoroafor and U. A. Osunkwo. 2011. Evaluation of the anti-diarrheal activity of methanol leaf extract of Bombax buonopozense in rats. Ibnosina J. Med. BS. 3(1): $15-20$.

Balaji, G., M. Chalamaiah, B. Ramesh and Y. R. Amarnath. 2012. Antidiarrhoeal activity of ethanol and aqueous extracts of Carum copticum seeds in experimental rats. Asian Pac. J. Trop. Biomed. 2(2): 1151-1155.

Besra, S. E., A. Gomes, L. Chaudhury, J. R. Vedasiromoni and D. K. Ganguly. 2002. Antidiarrheal activity of seed extract of Albizzia lebbek Benth. Phytother. Res. 16: 529-533.

Brijesh, S., P. Daswani, P. Tetali, N. Antia and T. Birdi. 2009. Studies on the antidiarrhoeal activity of Aegle marmelos unripe fruit: Validating its traditional usage. $B M C$ Complement Altern. Med. 9(47): 1-12.

Chowdhury, F., I. A. Khan, S. Patel, A. U. Siddiq, N. C. Saha, A. I. Khan, A. Saha, A. Cravioto, J. Clemens, F. Qadri and M. Ali. 2015. Diarrheal illness and healthcare seeking behavior among a population at high risk for diarrhea in Dhaka, Bangladesh. PLOS ONE. 10(6): e0130105.

Das, A. J., R. Kumar, M. Athar, D. S. Rawat, M Kumar, M. A. Khan MA and J. Prakash. 2013. Ethno medicinal study of threatened plants of Sonitpur district in Assam, North East India. IRJP. 4: 146-149.

El-Kaissi, S. and S. Sherbeeni. 2011. Pharmacological management of type 2 diabetes mellitus: an update. Curr. Diabetes Rev. 7(6): 392-405. 
Ernawita, R. A. Wahyuono, J. Hesse, U. C. Hipler, P. Elsner and V. Böhm. 2016. Carotenoids of indigenous citrus species from Aceh and its in vitro antioxidant, antidiabetic and antibacterial activities. Eur. Food Res. Technol. 242: 1869-1881.

Gutiérrez, S. P., D. Z. Mendoz, A. H. Munive, A. M. Martínez, C. P. González and E. S. Mendoza. 2013. Antidiarrheal activity of 19-deoxyicetexone isolated from Salvia ballotiflora Benth in mice and rats. Molecules. 18: 8895-8905.

Gyo-Nam, K., S. Jung-Geun and J. Hae-Dong. 2009. Antioxidant and antidiabetic activity of Dangyuja (Citrus grandis Osbeck) extract treated with Aspergillus saitoi. Food Chem. 117: 35-41.

Havagiray, R. C., C. Ramesh, and K. Sadhna. 2004. Studies on anti-diarrheal activity of Calotropis gigantean in experimental animals. J Pharm. Pharmaceut. Sci. 7(1): 70-75.

Jung, U. J., M. K. Lee, Y. B. Park, M. A. Kang and M. S. Choi. 2006. Effect of citrus flavonoids on lipid metabolism and glucoseregulating enzyme mRNA levels in type-2 diabetic mice. Int. J. Biochem. Cell Biol. 38: 1134-1145.

Kabra, A. O., G. B. Bairagi and R. S. Wanare. 2012. Antidiabetic activity of ethanol extract of Citrus medica L. peels in streptozotocin induced diabetic rats. $J$. Pharm Res. 5(3): 1287-1289.

Keerthana, G., M. K. Kalaivani and A.

Sumathy. 2013. In-vitro alpha amylase inhibitory and anti-oxidant activities of ethanolic leaf extract of Croton bonplandianum. Asian J. Pharm. Clin. Res. 6(4): 32-36.

Khandaker, S., S. Das, F. A. D. M. Opo, R. Akhter and M. Shahriar. 2016. In vivo pharmacological investigations of the crude extracts of Calamus viminalis (L.). Journal of Pharmacognosy and Phytochemistry. 5(3): 263-269.

Kumar, B. D., A. Mitra and M. Manjunatha. 2010. A comparative study of alpha-amylase inhibitory activities of common antidiabetic plants of Kharagpur 1 block. Int. J. Green Pharm. 4: 115-121.
KunduSen, S., P. K. Haldar, M. Gupta, U. K. Mazumder, P. Saha, A. Bala A, S. Bhattacharya and B. Kar. 2011. Evaluation of antihyperglycemic activity of Citrus limetta fruit peel in streptozotocin-induced diabetic rats. ISRN Endocrinol. 2011: 869273.

Laboni, F. R., S. Mahmud, S. Karim, S. Das S and M. Shahriar. 2017. Biological investigations of different leaf extracts of Litsea liyuyingi (Family-Lauraceae). IOSR J. Pharm. Biol. Sci. 12(2): 08-17.

Lucker, J., M. K. Tamer, W. Schwab, F. W. A. Verstappen, L. H. W. V. Plas, H. J. Bouwmesster and H.A. Verhoeven. 2002. Monoterpene biosynthesis in lemon (Citrus limon). Eur. J. Biochem. 269: 3160-3171.

Mahmood, A., M. S. Islam, S. Parvin, M. M. N. Uddin and M. Shahriar. 2013. Phytochemical screenings and antithrombolytic activity of Citrus assamenses. IJDT. 4: 98-100.

Marona, H. R. N. and M. B. B. Lucchesi. 2004. Protocol to refine intestinal motility test in mice. Laboratory Animals. 38: 257-260.

McCue, P., D. Vattem and K. Shetty. 2004. Inhibitory effect of Clonal oregano extracts against porcine pancreatic amylase in vitro. Asia. Pac. J. Clin. Nutr. 13: 401-408.

Meyer, H. 1890. Ueber den wirksamen Bestandtheil des Ricinusöls. [On the active component of castor oil.] Arch Exp Path Pharmak. German. 28: 145-152.

Miller, G. L. 1959. Use of dinitrosalicylic acid reagent for determination of reducing sugar. Anal Chem. 31: 426-428.

Naim, M., F. M. Amjad, S. Sultana, S. N. Isalm, M. A. Hossain, R. Begum, M. A. Rashid and M. S. Amran. 2012. A comparative study of antidiabetic activity of hexane-extract of lemon peel (Limon citrus) and glimepiride in alloxan-induced diabetic rats. Bangladesh Pharm. J. 15(2): 131-134.

OECD/OCDE, OECD Guidelines for the testing of chemicals, revised draft guidelines 423: Acute Oral toxicity- Acute toxic class method, revised document, CPCSEA, Ministry of Social Justice and Empowerment. 2000 New Delhi: Government of India. 
Oyedepot, A. and S. O. Babarinde. 2012. Effects of shaddock (Citrus maxima) fruit juice on glucose. Chem. Sci. Trans. 2(1): 19-24.

Palombo, E. A. 2006. Phytochemicals from traditional medicinal plants used in the treatment of diarrhoea: Modes of action and effects on intestinal function. Phytother. Res. 20: 717-724.

Peng, C. H., Y. B. Ker, C. F. Weng, C. C. Peng, C. N. Huang, L. Y. Lin and R. Y. Peng. 2009. Insulin secretagogue bioactivity of finger citron fruit (Citrus medica L. var. Sarcodactylis Hort, Rutaceae). J. Agric. Food Chem. 57(19): 8812-8819.

Ranilla, L. G., Y. I. Kwon, E. Apostolidis and K. Shetty. 2010. Phenolic compounds, antioxidant activity and in vitro inhibitory potential against key enzymes relevant for hyperglycemia and hypertension of commonly used medicinal plants, herbs and spices in Latin America. Bioresour. Technol. 101(12): 4676-4689.

Roberts, L. J., J. A. Oates, M. F. Linton, S. Fazio, B. P. Meador, M. D. Gross, Y. Shyr, and J. D. Morrow. 2007. The relationship between dose of vitamin $\mathrm{E}$ and suppression of oxidative stress in humans. Free Radic. Biol. Med. 10: 1388-1393.

Shemsu, U., T. Alemu and K. Nigatu. 2013. Antidiarrhoeal and antimicrobial activity of Calpurnia aurea leaf extract. BMC Complement Altern. Med. 13: 21.

Sunilson, J. A. J., K. Anandarajagopal, A. Kumari A and S. Mohan. 2009. Antidiarrhoeal activity of leaves of Melastoma malabathricum linn. Indian J. Pharm. Sci. 71: 691-695.

Tadesse, W. T., A. E. Hailu, A. E. Gurmu and A. F. Mechesso. 2014. Experimental assessment of antidiarrheal and antisecretory activity of $80 \%$ methanolic leaf extract of Zehneria scabra in mice. BMC Complement. Altern. Med. 14: 460.
The American Diabetes Association. 2012. Diagnosis and classification of diabetes mellitus. Diabetes Care. 35(1): 64-71.

Uddin, N., M. R. Hasan, M. M. Hossain, A. Sarker, A H. M. N. Hasan, A. F. M. M. Islam, M. M. Chowdhury and M. S. Rana. 2014. In vitro $\alpha$ amylase inhibitory activity and in vivo hypoglycemic effect of methanol extract of Citrus macroptera Montr. fruit. Asian Pac. J. Trop. Biomed. 4: 473-479.

Vasu, P., N. D. Khan, Z. H. Khan and S. M. Mular. 2017. In vitro antidiabetic activity of methanolic extract of Citrus limon, Punica granatum, Musa acuminata peel. IJAR. 3(4): 804-806.

Wadkar, K. A., C. S. Magdum, S. S. Patil and N. S. Naikwade. 2008. Anti-diabetic potential and Indian medicinal plant. J. Herbal Med. and Toxicol. 2(1): 45-50.

Watson, W. C. and R. S. Gordon. 1962. Studies on the digestion, absorption and metabolism of castor oil. Biochem. Pharmacol. 11: 229236.

WHO. 2013. Ending preventable child deaths from pneumonia and diarrhoea by 2025.1-56.

Wickramaratne, M. N., J. C. Punchihewa and D. B. M. Wickramaratne. 2016. In-vitro alpha amylase inhibitory activity of the leaf extracts of Adenanthera pavonina. BMC Complement. Altern. Med. 16: 466.

Yoshio, K., S. Kazuko, M. Bunsyo, H. Kazunori, I. Atsushi and K. Yasuhiro. 1999. Relationship between antidiarrhoeal effects of Hange Shashin-To and its active components. Phytother. Res. 13: 468-473.

(Received revised manuscript on 25 September 2018) 